\title{
Coordinated expression and immunogenicity of an outer membrane protein from Salmonella enterica serovar Typhi under iron limitation, oxidative stress and anaerobic conditions
}

\author{
V. Chanana ${ }^{1}$, S. Majumdar ${ }^{2}$, P. Ray ${ }^{3}$, M. Sharma ${ }^{3}$ \& P. Rishi ${ }^{1, *}$ \\ ${ }^{1}$ Department of Microbiology, Panjab University, Chandigarh, 160014, India; ${ }^{2}$ Department of Experimental \\ Medicine and Biotechnology, Post Graduate Institute of Medical Education and Research (PGIMER), \\ Chandigarh, 160012, India; ${ }^{3}$ Department of Medical Microbiology, Post Graduate Institute of Medical \\ Education and Research (PGIMER), Chandigarh, India
}

Received 22 July 2005; accepted 24 October 2005

(C) 2005 National Science Council, Taipei

Key words: expression, Salmonella typhi, stress protein

\begin{abstract}
Summary
Successful pathogens overcome the environmental stresses by the coordinated expression of various genes and eventually proteins. Since, the surface of the microbe is likely to come in contact with the host initially, an attempt was made to identify the outer membrane proteins (OMPs), if any, which may get expressed under more than one environmental conditions simulating the in vivo ones. In the present study, Salmonella enterica serovar Typhi was grown under iron-limited, oxidative stress as well as anaerobic conditions and the OMP profiles were compared. A $69 \mathrm{kDa}$ OMP was found to express with enhanced intensity under the selected stress conditions in comparison to normal conditions. The phenotypic similarity among the proteins was assessed on the basis of their molecular weight, cross reactivity and HPLC. The protein expressed under oxidative stress and anaerobic conditions reacted with the antibodies raised against iron-regulated outer membrane protein (IROMP), indicating the sharing of at least some of the epitopes. A single peak observed after subjecting the pooled $69 \mathrm{kDa}$ protein sample and appearance of a single band on SDS-PAGE thereafter, confirmed the purity and phenotypic similarity of the $69 \mathrm{kDa}$ OMP. Reactivity of pooled $69 \mathrm{kDa}$ protein with $85 \%$ of sera from typhoid patients revealed the in vivo expression of this protein. The results of this study indicate the coordination of this phenotype under iron stress, oxidative stress and anaerobic conditions. In view of the expression of the $69 \mathrm{kDa}$ protein under the selected stress conditions and their in vivo immunogenicity, these findings may be relevant for the better understanding of the host-microbe interactions and for the further development of diagnostic and preventive strategies.
\end{abstract}

\section{Introduction}

Typhoid fever is a human disease caused by Salmonella enterica serovar Typhi, a facultative, intracellular pathogen. This disease remains a major public health problem due to significant

*To whom correspondence should be addressed. Fax: +91-1722541770; E-mail: rishipraveen@yahoo.com morbidity and mortality worldwide and therefore, continues to be a priority of the World Health Organization. After S. typhi is ingested through contaminated food and/or water, the organism migrates to distal ileum. Presumably, S. typhi, then adheres to and invades the intestinal epithelium, migrates to the underlying Peyer's patches and disseminates throughout the reticuloendothelial system [1]. However, little is known about the 
bacterium-host interactions that occur at each of these steps in the pathogenesis of S. typhi.

Like other enteric pathogens, Salmonella typhi encounters iron limitation during the disease process, as the human body has different iron withholding defense systems, preventing the organism from acquiring essential iron for surviving inside the host [2]. Besides iron limitation, availability of oxygen, is yet another stress encountered by $S$. typhi while using molecular oxygen for respiration or oxidation of nutrients to obtain energy and within the intracellular milieu of macropahge-phagolysosomes as well. This results in continuous generation of reactive oxygen species, such as anion radical $\left(\mathrm{O}_{2}\right)$, hydrogen peroxide $\left(\mathrm{H}_{2} \mathrm{O}_{2}\right)$ and highly reactive hydroxyl radicals $(\mathrm{OH})^{-}$[3]. Anaerobic conditions are also frequently encountered by pathogens invading the gastrointestinal tract due to low/limiting oxygen conditions prevalent in the small intestine [4, 5]. However, the regular interaction of the host and the pathogen causes the latter to express certain regulons for sensing the host environments and develop survival strategies against the environmental stresses [2, 6]. Although, a number of genes including fur, sox $R / S$, mar $A$, oxy $R$ have been identified, for combating these stresses [7-10], there are not many studies indicating the identification and localization of the proteins involved in pathogenesis under these conditions.

There is some indication from the existing literature that if stress tolerance occurs in a bacterium when exposed to a single stressor, cross protection can be manifested across multiple stresses and general tolerance of these environments is increased $[10,11]$. Iron responsive regulator Fur has been found to be directly or indirectly involved in regulation of oxidative stress defense [12]. Iron regulation has been reported to confer resistance against oxidative stress too, as the organisms are also exposed to extracellular oxygen metabolites of stimulated polymorphonuclear phagocytes in the infected gut. The limited availability of iron in mucosal secretions, in tissues and within the phagocytes, due to the bound iron is well known. The link between iron metabolism and oxidative stress is further demonstrated by the results that the primary regulators of the oxidative stress response in E. coli i.e. OxyR and SoxRS induce the synthesis of Fur and that the E. coli fur mutant is hypersensitive to oxidative stress [3, 9]. It is clear from these studies that the pathogens evolve strategies to overcome the stresses by coordinated expression of genes and proteins. However, very little is known about the coordination of phenotype(s) expression and availability of iron and oxygen particularly with respect to outer membrane proteins.

The outer membrane proteins of bacteria function as the dynamic interface between the bacterium and its surroundings and are involved in the maintenance of cell structure, binding a variety of substances adhesion to other cells, and regulation of transport of both nutrients and bactericidal agents [13]. There is a vast amount of information about OMPs and their roles in virulence, inflammation, immunogenicity and anti-microbial resistance [14-16]. However, the knowledge about the expression of OMPs of the bacteria, in reference to coordination of iron and oxygen availability is largely not available. The present study was therefore; carried out to evaluate the coordinated expression of signal sensing phenotype(s) in serovar Typhi under the environmental conditions to mimic the in vivo environmental milieu.

\section{Materials and methods}

\section{Animals}

Young male New Zealand white rabbits (1-2 kg in weight) used for raising anti-sera, were procured from Central Animal House, Panjab University, Chandigarh. Care and use of laboratory animals was followed, in accordance with the guidelines of the institutional ethical committee.

\section{Microorganisms}

The standard strain of $S$. enterica serovar Typhi (Ty2) procured from CRI Kasauli, India, was used in the present study. The strain was checked for its purity and was characterized biochemically as well as serologically. It was maintained in $10 \%$ glycerol broth and also stored as lyophilized ampules.

\section{Growth conditions}

Bacteria was grown on nutrient agar plates and single colony was used to prepare seed culture. $0.1 \%$ inoculum from seed culture was 
used for growing the bacteria under stress conditions.

\section{Iron stress}

Cells were grown in nutrient broth under irondepleted conditions created by adding different concentrations of iron chelator $2,2^{\prime}$-dipyridyl ( 100 , 150,200 and $250 \mu \mathrm{M}$ ) in accordance with the method originally described by Fernandez-Beros et al. [17]. Iron content of the media before and after chelation was measured by the method of Carter [18]. The concentration of dipyridyl that could induce the maximum expression of IROMP(s) was chosen for the subsequent experiments. Iron-sufficient conditions were created by adding ferrous sulphate in growth medium using the concentration comparable to the concentration of the iron chelator.

\section{Oxidative stress}

For the oxidative stress, $S$. Typhi cells were exposed to different concentrations of hydrogen peroxide $(10,15$ and $20 \mathrm{mM})$ in accordance with the method of Ozkanca et al. [19]. The cells were grown in nutrient broth and hydrogen peroxide was added to the culture medium in the early logarithmic phase. The cells were allowed to grow overnight at $37^{\circ} \mathrm{C}, 150 \mathrm{rpm}$ and were harvested in the stationary phase. The concentration of $\mathrm{H}_{2} \mathrm{O}_{2}$ that could induce the maximum expression of oxidative stress induced OMP(s) was chosen for the subsequent experiments.

\section{Anaerobic stress}

The bacteria were cultured by growing in nutrient broth, under anaerobic conditions by the method of Schimann and Shope [20]. Anaerobic conditions were maintained by placing the culture in Mackintosh anaerobic chamber in the presence of $85 \%$ nitrogen, $10 \% \mathrm{H}_{2}$ and $5 \% \mathrm{CO}_{2}$. The chamber was kept at $37{ }^{\circ} \mathrm{C}$ overnight and the cells were harvested.

\section{Combined stress}

The bacteria were subjected to the combined stress of iron and oxygen by growing the cells in nutrient broth under iron depleted conditions created by the addition of $2,2^{\prime}$,-dipyridyl as described earlier and $S$. Typhi cells were then exposed to hydrogen peroxide $(15 \mathrm{mM})$ in the early logarithmic phase of growth as described by the method of Ozkanca et al. [19]. The cells were allowed to grow overnight at $37^{\circ} \mathrm{C}, 150 \mathrm{rpm}$ and were harvested in the stationary phase.

\section{Extraction of OMPS}

To study the expression of stress-induced proteins, OMPs were prepared according to the method described by Chander et al. [21]. Briefly, cells were grown under selected stress conditions as described earlier. Bacterial growth was harvested and the pellet obtained was suspended in $20 \mathrm{mM}$ Tris $-\mathrm{HCl}$ buffer ( $\mathrm{pH}$ 7.6) containing $5 \mathrm{mM} \mathrm{MgCl}_{2}$. Cells were harvested twice and suspended in the same buffer containing $2 \mathrm{mM}$ phenyl methyl sulphonyl fluoride (PMSF, Sigma, USA). Cells were then disrupted by ultrasonication and undisrupted material was removed by low speed centrifugation. Supernatant was then ultracentrifuged (Beckman Coulter, Optima ${ }^{\mathrm{TM}}$ XL-100K Ultracentrifuge, USA) at $100,000 \times g$ for $60 \mathrm{~min}$ at $4{ }^{\circ} \mathrm{C}$ and the pellet was suspended in $1 \%$ sodium lauryl sarcosyl (ICN, USA) (in $20 \mathrm{mM}$ Tris- $\mathrm{HCl}$ buffer, $\mathrm{pH}$ 7.6) for $2 \mathrm{~h}$ at $37^{\circ} \mathrm{C}$. Detergent insoluble OMP fraction was collected by ultracentrifugation at the same speed.

\section{Analysis of OMP profile}

The protein content in each preparation was estimated by the method of Markwell and Tolbery [22]. The proteins were separated on SDS-PAGE as described by Laemmli [23]. The molecular weight of the protein(s) expressed with enhanced intensity under iron stress, oxidative stress as well as anaerobic stress conditions was determined by calculating the relative front (Rf) values in comparison to that of standard molecular weight markers [phosphorylase B (97 kDa), bovine serum albumin $(66 \mathrm{kDa})$, ovalbumin $(43 \mathrm{kDa})$ and carbonic anhydrase (29 kDa)]. Densitometric analysis of stress induced OMPs was determined using GENE TOOL software on GEL DOCUMENTATION (Syngene, USA). For this, one of the protein bands in the marker lane was taken as 1 . Then the protein of interest expressed with 
enhanced intensity was quantified as how many times of the marker band.

\section{Elution of stress induced OMP from polyacrylamide gels}

Stress induced OMPs were eluted out of the preparative gel by the method of Hager and Burgess [24]. Briefly, OMPs extracted from pathogen grown under different stress conditions as described earlier, were resolved on SDS-PAGE and the region expressing stress induced OMP was excised from the gel. Gel section was chopped into small pieces and crushed. Proteins were eluted by incubating the crushed mass of gel with elution buffer for overnight at $4{ }^{\circ} \mathrm{C}$. The mixture was centrifuged and the supernatant was then transferred to a fresh vial. Four volumes of ice-cold acetone was added to the gel eluate and the sample was allowed to precipitate for $30 \mathrm{~min}$ at $-20{ }^{\circ} \mathrm{C}$. The precipitation was then centrifuged $(27,000 \times g$, $10 \mathrm{~min}$ ) and supernatant was drained out. The recovery of the protein was checked on SDSPAGE by silver staining.

\section{Phenotypic similarity amongst the stresses induced proteins}

Phenotypic similarity amonst the stress induced proteins was determined on the basis of (i) Identical molecular weight: for this, the bands corresponding to the protein of interest were excised and eluted from respective gels [24] as described before. The three proteins were then pooled and run on the SDS-PAGE again. The gel was silver stained by the method of Budowle et al. [25] (ii) Cross reactivity: for this, the anti-serum against iron regulated outer membrane protein (IROMP) was raised in rabbits according to Claire et al. [26]. The titre of the antibodies was checked by ELISA [27]. Cross reactivity of oxidative and anaerobic stress induced proteins with IROMP was assessed using anti-IROMP anti-serum and anti-rabbit IgG HRP conjugate (Dako Inc. USA) by Western blotting [28]; and (iii) $H P L C$ : for this, the selected stress induced outer membrane proteins were pooled and subjected to high performance liquid chromatography (HPLC) (Shimadzu). Analytical details for HPLC included; Column - Shim-pack DIOL-150, $7.9 \mathrm{~mm}$ ID $\times 25 \mathrm{~cm}$; Mobile phase $-0.2 \mathrm{M}$ sodium sulfate in $0.01 \mathrm{M}$ phosphate buffer, $\mathrm{pH}$ 7.0; Flow rate $1.0 \mathrm{ml} / \mathrm{min}$; Temperature $-22{ }^{\circ} \mathrm{C}$; Detector $280 \mathrm{~nm}$.

\section{In-vivo expression of the stress-induced phenotype}

In-vivo immunogenicity of the selected stressinduced OMP was detected by Western blotting, using sera from 20 typhoid fever patients (Widal positive sera). The sera from six apparently healthy individuals were used as controls. For this, outer membrane proteins extracted from $S$. Typhi grown under iron stress, oxidative stress as well as anaerobic stress were resolved on SDSPAGE. Resolved proteins were transferred onto the nitrocellulose paper (NCP) as described previously [28] at $200 \mathrm{~mA}$ for $3 \mathrm{~h}$. The NCP containing the transferred antigen (OMPs) was blocked with $5 \%(\mathrm{w} / \mathrm{v})$ skimmed milk in PBS for $2 \mathrm{~h}$ at $37^{\circ} \mathrm{C}$. Thereafter, NCP was incubated with 1:1500 diluted anti-human IgG HRP conjugate (Dako Inc. USA) for $1 \mathrm{~h}$ at $37^{\circ} \mathrm{C}$. Strips were then washed with washing solution for 3-4 times and then with PBS. The developing was done with 3,3'diaminobenzidine (DAB) (Sigma Chemical Co. USA) acting as a substrate (5 mg DAB in $10 \mathrm{ml}$ PBS with $5 \mu \mathrm{H}_{2} \mathrm{O}_{2}$ ). The reaction was stopped with double distilled water.

\section{Results}

\section{Analysis of outer membrane proteins}

A number of proteins were found to be expressed by $S$. Typhi as assessed by SDS-PAGE. On analyzing the protein profiles, it was interesting to note that a protein having molecular weight of $69 \mathrm{kDa}$ (determined by calculating $\mathrm{Rf}$ value) was getting expressed with high intensity under all the selected stress conditions. On comparing the expression of this protein under different concentrations of dipyridyl, it was found that the expression was maximum at $200 \mu \mathrm{M}$, than at 150 or $250 \mu \mathrm{M}$ concentration of dipyridyl (Figure 1). On exposing the bacteria to different concentrations of $\mathrm{H}_{2} \mathrm{O}_{2}(10,15$ and $20 \mathrm{mM})$, the expression of the $69 \mathrm{kDa}$ OMP was found to be highest at $15 \mathrm{mM}$ concentration of $\mathrm{H}_{2} \mathrm{O}_{2}$ (Figure 2). Enhanced expression of the $69 \mathrm{kDa}$ phenotype was also observed when $S$. Typhi was grown 


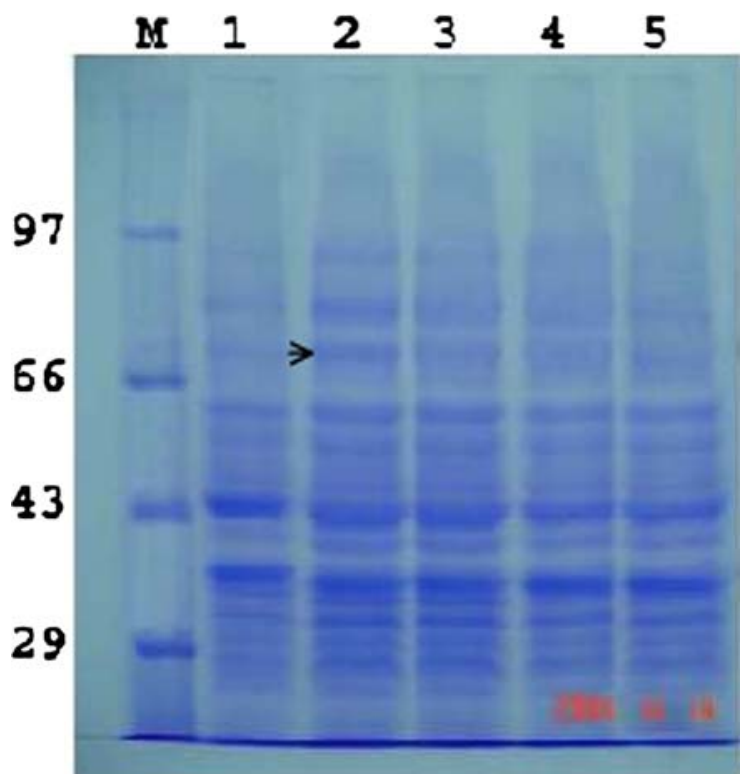

Figure 1. Analysis of outer membrane protein preparations following iron stress at different concentrations of dipyridyl by SDS-PAGE $(10 \%)$. Lane M, Molecular weight standards; lane 1, OMPs extracted under normal conditions (nutrient broth, $150 \mathrm{rpm}, 37^{\circ} \mathrm{C}$ overnight); lane 2, OMPs extracted at $200 \mu \mathrm{M}$ concentration of dipyridyl; lane 3, OMPs extracted at $100 \mu \mathrm{M}$ concentration of dipyridyl; lane 4, OMPs extracted at $150 \mu \mathrm{M}$ concentration of dipyridyl; lane 5, OMPs extracted at $250 \mu \mathrm{M}$ concentration of dipyridyl.

under anaerobic conditions (Figure 3). However, this protein was not found to be expressed when the cells were grown under normal and ironsufficient conditions. On subjecting serovar Typhi to the combined stress of iron and oxygen, enhanced expression of $69 \mathrm{kDa}$ OMP was again evident (Figure 4) and the protein profile observed in this case was identical to the OMP profile observed in the presence of iron stress (Figure 1), oxidative stress (Figure 2) and anaerobic stress (Figure 3). The GENE TOOL software on GEL DOCUMENTATION (Syngene, USA) revealed that the protein expression of $60 \mathrm{kDa}$ increased by 3.6-fold in iron stress, 3.2-fold in oxidative stress and 3.4-fold in anaerobic stress conditions, as compared to the control.

\section{Phenotypic similarity}

As the molecular weight is always apparent, the phenotypic similarity among the proteins was assessed on the basis of their identical molecular weight, cross reactivity and HPLC. When the

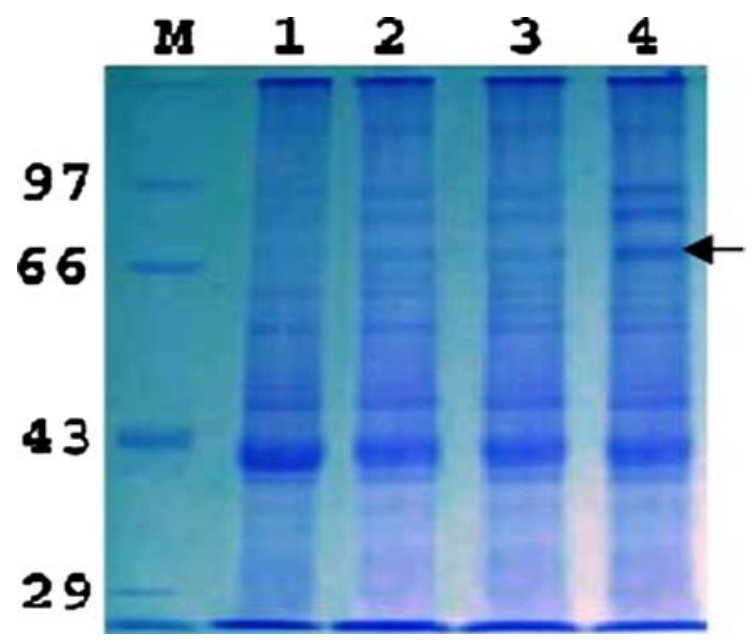

Figure 2. Analysis of outer membrane protein preparations following oxidative stress at different concentrations of hydrogen peroxide $\left(\mathrm{H}_{2} \mathrm{O}_{2}\right)$ by SDS-PAGE $(10 \%)$. Lane M, Molecular weight standards; lane 1, OMPs extracted under normal conditions (nutrient broth, $150 \mathrm{rpm}, 37^{\circ} \mathrm{C}$ overnight); lane 2, OMPs extracted at $10 \mathrm{mM}$ concentration of hydrogen peroxide; lane 3, OMPs extracted at $20 \mathrm{mM}$ concentration of hydrogen peroxide; lane 4, OMPs extracted at $15 \mathrm{mM}$ concentration of hydrogen peroxide.

protein expressed under all the stress conditions were eluted separately, pooled and analyzed on SDS-PAGE by silver staining, a single band appeared at the same position as in the unpooled samples indicating the similarity of this protein (in terms of identical molecular weight under the selected conditions) (Figure 5). Western blot analysis revealed the cross reactivity (Figure 6) of oxidative-stressed and anaerobic-stressed protein with anti-IROMP anti-serum (raised against the iron-stressed OMP shown in Figure 1). On analyzing the HPLC chromatogram, a single peak with a small shoulder was observed (Figure 7a). Therefore, the fractions containing the peak were pooled and were again subjected to SDS-PAGE followed by silver staining. A single band observed thereafter confirmed the purity of the pooled protein (Figure 7b).

In vivo expression

The in vivo expression of this stress induced OMP(s) was revealed indirectly by the in vivo immunogenicity indicated by the reactivity of these proteins with sera of typhoid patients. Out of 20 typhoid patients sera (Widal-positive) tested, 17 


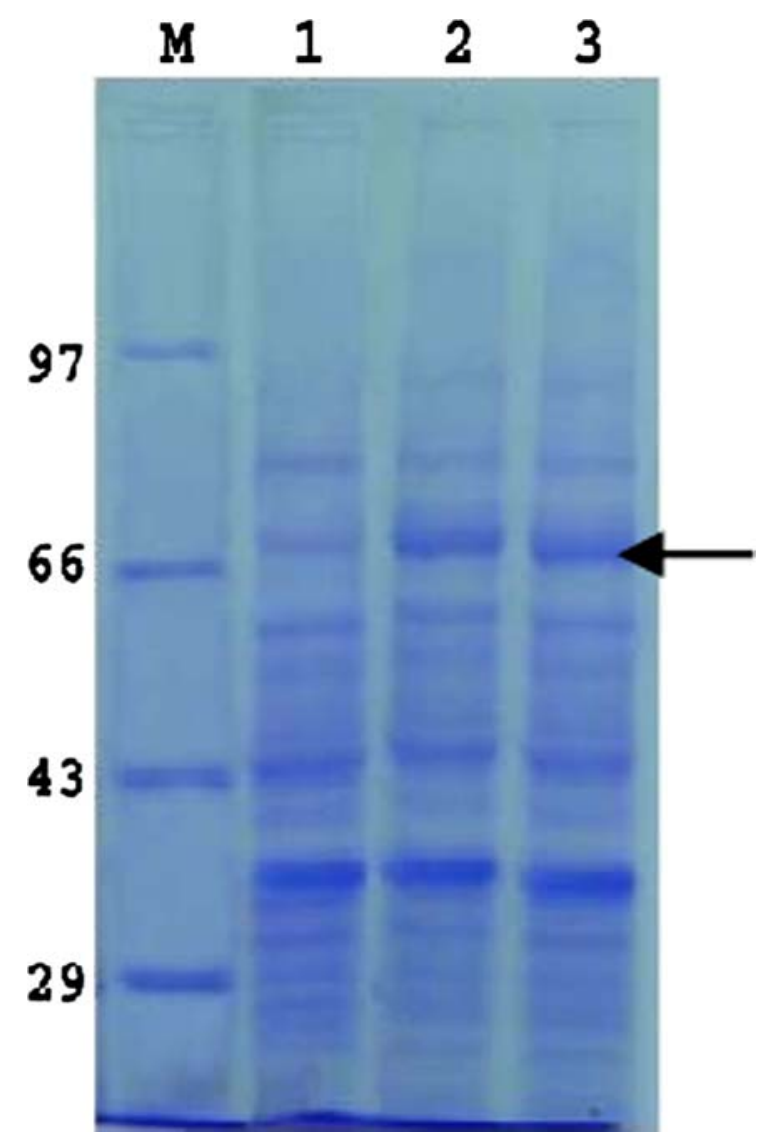

Figure 3. Analysis of outer membrane protein preparations of $S$. Typhi, grown under anaerobic conditions, by SDS-PAGE $(10 \%)$. Lane M, Molecular weight standards; lane 1, OMPs extracted under normal conditions (nutrient broth, $150 \mathrm{rpm}$, $37^{\circ} \mathrm{C}$ overnight); lane $2 \& 3$, OMPs extracted under anaerobic conditions.

sera were recognized by all the three stress-induced OMP(s) (Figure 8). In contrast, none of the six normal sera from apparently healthy individuals reacted with these proteins.

\section{Discussion}

The pathogen is exposed to a variety of host environmental conditions that may influence the functional capacity. Such environmental cues include acidic $\mathrm{pH}$, elevated temperature, oxidative stress, different osmotic strengths and the presence of cationic peptides as well as the availability of ions and nutrients. As the infection proceeds, the expression of the virulence determinants varies with time and anatomical sites [6]. Therefore, our

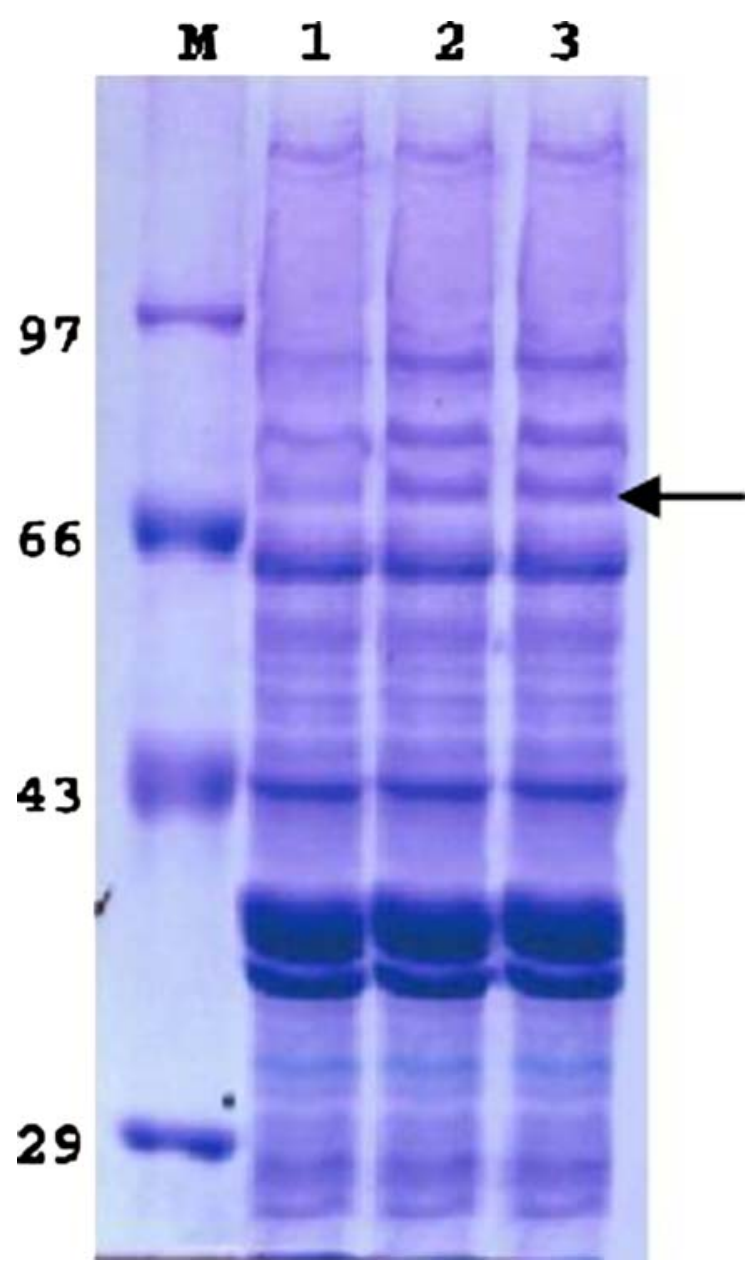

Figure 4. Analysis of outer membrane protein preparations of $S$. Typhi subjected to the combined stress of iron $(200 \mu \mathrm{M}$ dipyridyl) and oxidative $\left(15 \mathrm{mM} \quad \mathrm{H}_{2} \mathrm{O}_{2}\right)$ by SDS-PAGE $(10 \%)$. Lane M, Molecular weight standards; lane 1, OMPs extracted under normal conditions (nutrient broth, $150 \mathrm{rpm}$, $37^{\circ} \mathrm{C}$ overnight); lane $2 \& 3$, OMPs extracted from $S$. Typhi subjected to the combined iron and oxidative stress.

hypothesis is to identify the set of proteins, which may get expressed under different environmental conditions with an ultimate aim to develop a preventive intervention.

Several forms of stresses increase the rate of synthesis of stress genes and subsequently proteins expressed under different stress conditions. In response to the generation of resistance mechanisms in bacteria when exposed to a particular stress, cross protection has also been shown to manifest across multiple stresses [10, 11]. Baillon et al. [29] have shown that iron regulated proteins of Campylobacter jejuni are involved in its defense 


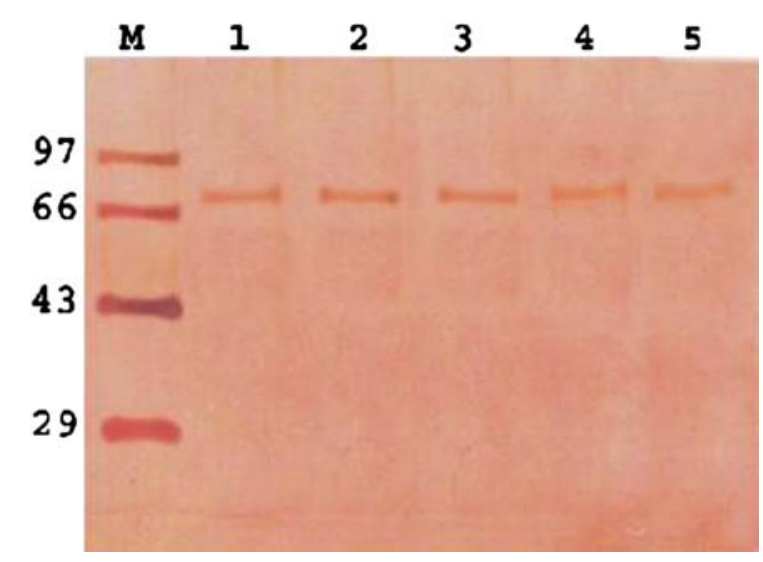

Figure 5. Analysis of stress induced $69 \mathrm{kDa}$ OMP under different conditions by SDS-PAGE $(10 \%)$ after chemical elution. Lane M, Molecular weight standards; lane 1, IROMP; lane 2, oxidative stress outer membrane protein; lane 3, anaerobic stress outer membrane protein; lane 4, OMP extracted under iron and oxidative combined stress; lane 5, pool of the above stress proteins.

against oxidative stress. Rocha et al. [30] have shown that response to oxidative stress in anaerobically grown $B$. fragilis induces the synthesis of at least 28 proteins in the presence of $\mathrm{H}_{2} \mathrm{O}_{2}$ that confers protection to the organism against the hydrogen peroxide induced oxidative damage. Pathogens have been reported to combat these stress conditions through the induction of various iron-regulated proteins [31, 16], oxidative stress proteins $[19,32]$ and anaerobic stressed proteins [33]. However, the coordination of phenotype(s) and their immunodominance under iron and oxygen availability have not been studied in detail. The present study revealed the expression, phenotypic similarity and immunodominance of the $69 \mathrm{kDa}$ signal sensing phenotype under these stress conditions. This protein may be one of the factors, which may help the organism to combat the stresses offered by the host.

Enhanced expression of the $69 \mathrm{kDa}$ OMP in all the selected stresses is suggestive of the hypothesis that stress may be responsible for a signal, which induces the synthesis of this protein, which then crosses the inner membrane to become associated with outer membrane. Fernandez-Beros et al. [17] and Baumler et al. [34] have also reported that iron regulated proteins observed in their study were also associated with the outer membrane. Cross reactivity of anti-IROMP anti-sera with both the oxidative and anaerobic stressed proteins

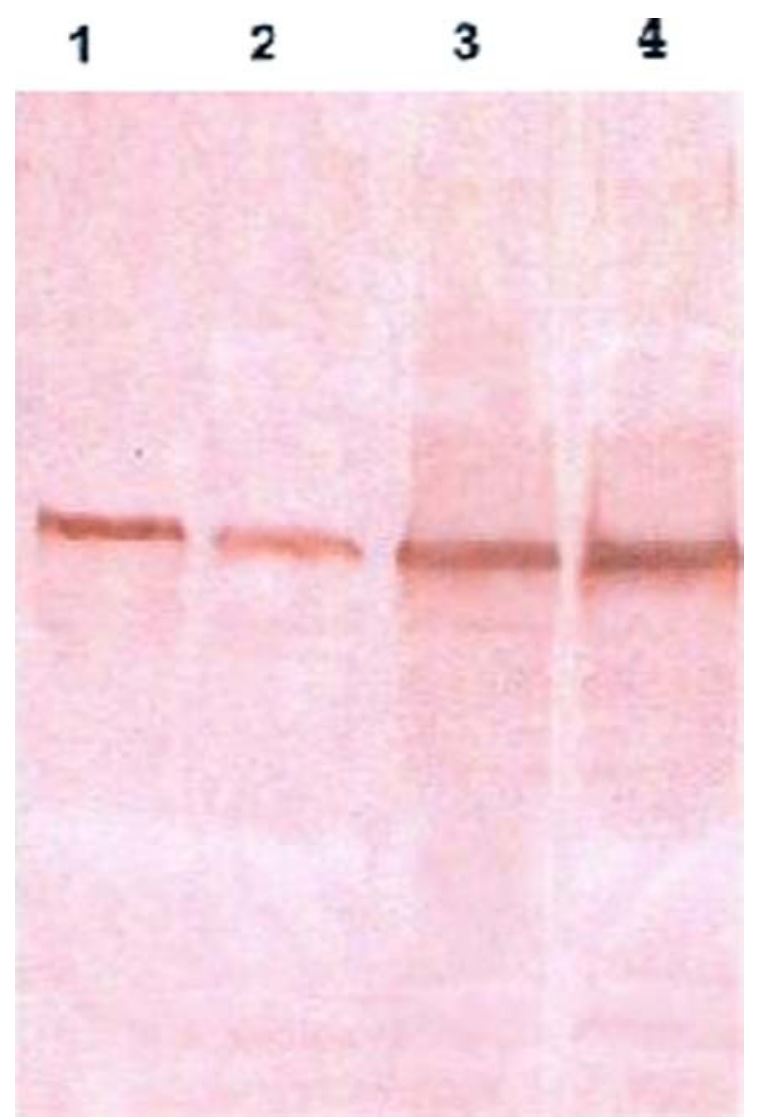

Figure 6. Western blot analysis showing the cross-reactivity of IROMP with oxidative, anaerobic and combined (iron and oxidative) stress induced protein using anti-IROMP antibodies. Lane 1, Iron stress protein; lane 2, oxidative stress protein; lane 3, anaerobic stress protein; lane 4, combined (iron and oxidative) stress protein.

indicates the sharing of atleast some of the epitopes expressed on these proteins under the stressed conditions. A single peak after subjecting the pooled $69 \mathrm{kDa}$ protein further confirmed the phenotypic similarity among the $69 \mathrm{kDa}$ OMP expressed under all the selected stress conditions and its purity. The ability of the organism to switch on a common regulatory network suggest that there is a class of 'stress regulated' genes that are regulated by common sensing mechanism in response to different environmental signals [6, 35]. The results of the present study indicating the overlapping expression of proteins under different stress conditions are in agreement with earlier studies of Chander et al. [21] and Ramamoorthy and Schoel-Meeker [36]. The results suggest that expression of proteins does not depend on single 

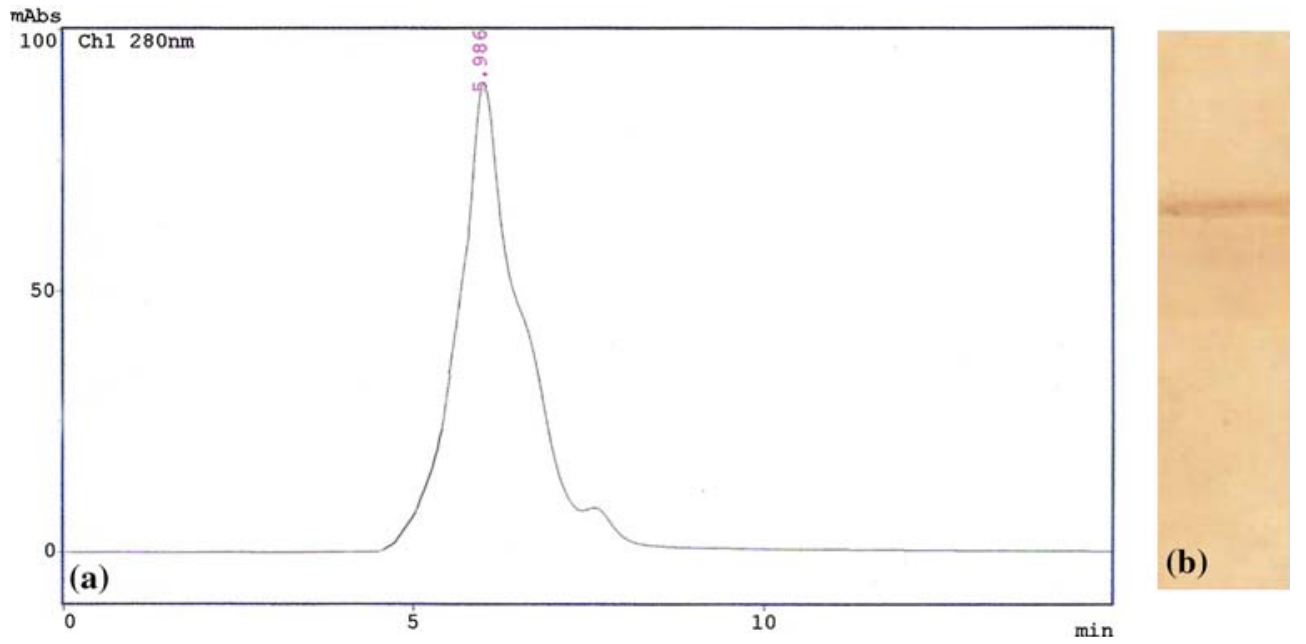

Figure 7. (a) Auto-scaled HPLC chromatogram of $69 \mathrm{kDa}$ stress protein. (b) Silver staining of purified $69 \mathrm{kDa}$ protein after HPLC.

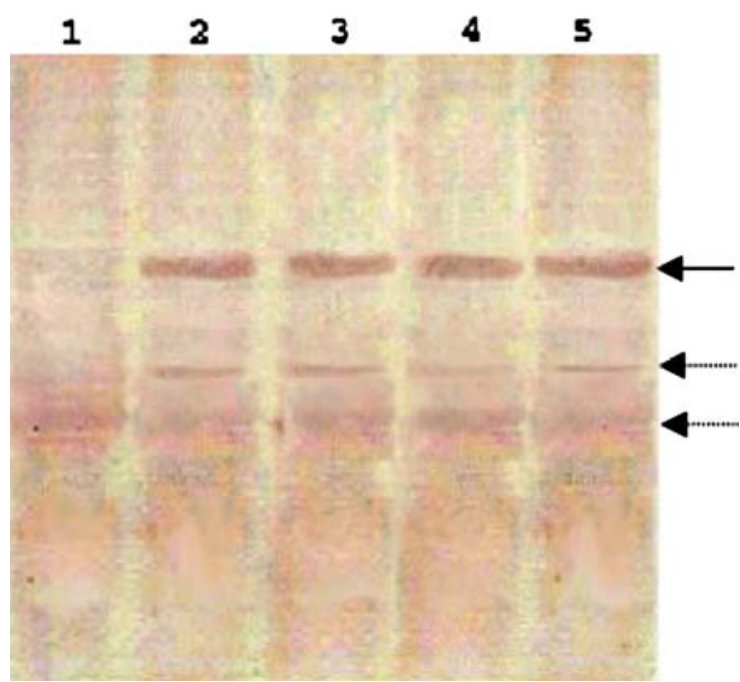

Figure 8. Immuno detection of $S$. Typhi stress induced outer membrane proteins with serum from patients with typhoid fever. lane 1, Normal outer membrane proteins; lane 2, iron stress proteins (IROMPs); lane 3, oxidative stress proteins; lane 4, combined (iron and oxidative) stress proteins. lane 5, anaerobic stress proteins; $\rightarrow$, indicates $69 \mathrm{kDa}$ protein; $\cdots \rightarrow$, indicates porins and other proteins.

environmental stimulus in host but there may be an interaction among stimuli. Expression of $69 \mathrm{kDa}$ phenotype under iron, oxidative and anaerobic stress conditions and their cross reactivity raises the question to confirm their identity in terms of commonality. Hence, our future goal is to compare their $\mathrm{N}$-terminal sequences and to evaluate their genetic expression under the selected conditions.
The in-vivo expression of this stress protein is indicated indirectly by its reactivity with the sera of typhoid fever patients. These results are in agreement with the earlier studies where IROMPs in the serovar Typhi were found to be immunogenic in-vivo [17]. Non-reactivity of two sera observed in our study can be due to the undefined stage of illness at the time of sample collection. Although the sera collected from patients suffering with pyrexia (but widal test negative) did not react with this protein, but sera from non-typhi Salmonella bacteremia patients along with a larger number of typhoid patient sera need to be explored to determine the specificity and the diagnostic utility of this protein.

In view of the expression of $69 \mathrm{kDa}$ OMP under iron limitation, oxidative stress as well as anaerobic conditions and its reactivity with the typhoid patient sera, it may be an important factor, induced during the evolution of salmonellosis. This finding may be relevant for the better understanding of the disease pathophysiology and for the future developments of diagnostic and preventive strategies.

\section{Acknowledgements}

The authors wish to thank Indian Council of Medical Research (ICMR), New Delhi, India, for providing financial assistance to carry out this project. 


\section{References}

1. Hornick R.B., Greisman S.E., Woodward T.E., Dupont H.L., Dawkins A.T. and Synder M.J., Typhoid fever: pathogenesis and immunological control. N. Engl. J. Med. 283: 739-746, 1970.

2. Ratledge C. and Dover L.G., Iron metabolism in pathogenic bacteria. Annu. Rev. Microbiol. 54: 881-941, 2000.

3. Farr S.B. and Kogoma T., Oxidative stress responses in Escherichia coli and Salmonella typhimurium. Microbiol. Rev. 55: 561-585, 1991.

4. Khullar M., Singh R.D., Smriti M. and Ganguly N.K., Anaerobiosis induced virulence of Salmonella enterica subsp. enterica serovar Typhimurium: role of phospholipase C signaling cascade. J. Med. Microbiol. 52: 741-745, 2003.

5. Krishnan H.H., Ghosh A., Paul K. and Chowdhury R., Effect of anaerobiosis on expression of virulence factors in Vibrio cholerae. Infect. Immun. 72: 3961-3967, 2004.

6. Smith H., What happens to bacterial pathogens in vivo. Trends Microbiol. 6: 239-243, 1998.

7. Harvie D.R., Vilchez S., Steggles J.R. and Ellar D.J., Bacillus cereus Fur regulates iron metabolism and is required for full virulence. Microbiology 151: 569-577, 2005.

8. Kozyrev D.P. and Vasinova N.A., The role of iron regulated genes in microbial pathogenesis. Tsitologiia 46: 465-473, 2004.

9. Straaten T., Zulianello L., Diepen A., Granger D.L., Janssen R. and Dissel J.T., Salmonella enterica serovar Typhimurium RamA, intracellular oxidative stress responses, and bacterial virulence. Infect. Immun. 72: 9961003, 2004.

10. Foster J.W. and Spector M.P., How Salmonella survive against the odds. Annu. Rev. Microbiol. 49: 145-174, 1995.

11. Archer D.L., Preservation microbiology and safety: evidence that stress enhances virulence and triggers adaptive mutations. Trends Food. Sci. Technol. 7: 91-95, 1996.

12. Ernst F.D., Homuth G., Stoof J., Mader U., Waidner B., Kuipers E.J., Kist M., Kusters J.G., Bereswill S. and Van Vliet A.H., Iron-responsive regulation of the Helicobacter pylori iron-cofactored superoxide dismutase SodB is mediated by Fur. J. Bacteriol. 187: 3687-3692, 2005.

13. Wexler H.M., Outer-membrane pore-forming proteins in gram-negative anaerobic bacteria. Clin. Infect. Dis. 35: $65-71,2002$

14. Sood S., Rishi P., Dhawan V., Sharma S. and Ganguly N.K., Protection mediated by antibodies to iron-regulated outer membrane proteins of $S$. typhi in a mouse peritonitis model. Mol. Cell. Biochem. 273: 421-423, 2005.

15. Sood S., Rishi P., Vohra H., Sharma S. and Ganguly N.K., Cellular immune response induced by Salmonella enterica serotype Typhi iron-regulated outer-membrane proteins at peripheral and mucosal levels. J. Med. Microbiol. 54: 815-821, 2005.

16. Chanana V., Seghal R. and Rishi P., Salmonella typhi ironregulated outer-membrane proteins cause oedema and hyperalgesia during inflammation induced in a rat model. J. Med. Microbiol. 54: 421-423, 2005.

17. Fernandez-Beros M.E., Gonzalez C., McIntosh M.A. and Cabello F.C., Immuneresponse to the iron deprivation induced proteins of $S$. typhi in typhoid fever. Infect. Immun. 57: 1271-1275, 1989.
18. Carter P., Spectrophotometric determination of serum iron at the submicrogram level with a new reagent (Ferrozine). Anal. Biochem. 40: 450-458, 1971.

19. Ozkanca R., Sahin N., Isik K., Kariptas E. and Flint K.P., The effect of toluidine blue on the survival, dormancy and outer membrane porin proteins $(\mathrm{OmpC}$ and $\mathrm{OmpF})$ and Salmonella typhimurium LT2 in seawater. J. Appl. Microbiol. 92: 1097-1104, 2002.

20. Schimann D.A. and Shope S.R., Anaerobic growth of Salmonella typhimurium results in increased uptake by Henle 407 epithelial and mouse peritoneal cells in vitro and repression of a major outermembrane protein. Infect. Immun. 59: 437-440, 1991 .

21. Chander H., Majumdar S., Sapru S. and Rishi P., Reactivity of typhoid patients sera with stress induced $55 \mathrm{kDa}$ phenotype in Salmonella enterica serovar Typhi. Mol. Cell. Biochem. 267: 75-82, 2004.

22. Markwell M.A.K. and Tolberi N.E., A modification of the Lowry procedure to simplify protein determination in membrane and lipoprotein samples. Anal. Biochem. 87: 206-210, 1978.

23. Laemmli U.K., Cleavage of structural proteins during the assembly of bacteriophage $T_{4}$. Nature 227: 680-685, 1970.

24. Hager D.A. and Burgess R.R., Elution of proteins from SDS-PAGE gels. Removal of SDS and renaturation of enzyme activity. Anal. Biochem. 109: 76-86, 1980.

25. Budowle B., Chakraborty R., Giusti A.M., Eisenberg A.J. and Allen R.C., Analysis of VNTR locus DIS 80 by the PCR followed by high resolution PAGE. Am. J. Hum. Genet. 48: 137-144, 1991.

26. Claire H., Fabrice P., Waligora-Dupriet Anne-Jubith, Anne C., Marie-Claude B. and Pierre B., GroEL (HSP 60) of Clostridium difficile is involved in cell adherence. Microbiology 147: 87-96, 2001.

27. Panezzuti H., James O., Hanson E.J., Choi Y., Harkmess R.E., Klein M.H. and Chang P., Identification of surface exposed B cell epitopes recognized by Haemophilus influenzae type $\mathrm{b}, \mathrm{P}$, specific monoclonal antibodies. Infect. Immun. 61: 1867-1872, 1993.

28. Towbin H., Staachelin T. and Gordon J., Electrophoretic transfer of proteins from acrylamide gels onto nitrocellulose sheet: procedure and some applications. Proc. Natl. Acad. Sci. USA 76: 4350-4354, 1979.

29. Baillon M.L., Van Vliet A.H., Ketley J.M., Constantinidou C. and Penn C.W., An iron-regulated alkyl hydroperoxide reductase $(\mathrm{AhpC})$ confers aerotolerance and oxidative stress resistance to the microaerophilic pathogen Campylobacter jejuni. J. Bacteriol. 181: 4798-4804, 1999.

30. Rocha E.R., Selby T., Coleman J.P. and Smith C.J., The oxidative stress response in an anaerobe, Bacteroides fragilis: a role for catalase in protection against hydrogen peroxide. J. Bacteriol. 178: 6895-6903, 1996.

31. Rabsch W., Methner U., Voigt W., TschapeH., Reissbrodt R. and Williams P.H., Role of receptor proteins for Enterobactin and 2,3-dihydroxybenzoylserine in virulence of Salmonella enterica. Infect. Immun. 71: 6953-6961, 2003.

32. Rocha E.R. and Smith C.J., Characterization of a peroxide resistant mutant of the anaerobic bacterium Bacteroides fragilis. J. Bacteriol. 180: 5906-5912, 1998.

33. Kapoor S., Singh R.D., Sharma P.C. and Khullar M., Anaerobiosis induced virulence of Salmonella typhi. Ind. J. Med. Res. 115: 184-188, 2002. 
34. Baumler A.J., Tsolis R.M., Fitch T.A. and Adams L.D. Evolution of host adaptation in Salmonella enterica. Infect. Immun. 66: 4579-4587, 1998.

35. Bhriain N.N., Dorman C.J. and Higgins C.F., An overlap between osmotic and anaerobic stress responses: a potential role for DNA supercoiling in the coordinate regulation of gene expression. Mol. Microbiol. 3: 933-942, 1989.

36. Ramamoorthy R. and Schoel-Meeker D., Borrelia Burgdorferi proteins whose expression is similarly affected by culture temperature and pH. Infect. Immun. 69: 2739-2742, 2001. 